DOI: 10.19112/2413-6174-2021-S1-25

\title{
ИЗУЧЕНИЕ ФАКТОРОВ ФОРМИРОВАНИЯ ЭЛЕМЕНТНОГО ДИСБАЛАНСА У ПОДРОСТКОВ РАЗНЫХ ЭТНИЧЕСКИХ ГРУПП ХАБАРОВСКОГО КРАЯ
}

\author{
А.О. Нестеренко ${ }^{1 *}$, Г.П. Евсеева ${ }^{2}$, Е.Д. Целых ${ }^{1}$ \\ ${ }^{1}$ Дальневосточный государственный университет путей сообщения, г. Хабаровск, Россия \\ ${ }^{2}$ Хабаровский филиал Дальневосточного научного центра физиологии и патологии дыхания - \\ НИИ охраны материнства и детства, г. Хабаровск, Россия \\ *e-mail: alenushka_3@inbox.ru
}

РЕЗЮМЕ. Проведено обследование подростков: нивхов, эвенов и русских. Выявлен элементный дисбаланс в сыворотке крови и волосах. Показана зависимость элементного состава биосубстратов от питания, территории, высокого содержания тория (Th) и урана (U) в организме.

КЛЮЧЕВЫЕ СЛОВА: подростки, микроэлементы, волосы, сыворотка крови, нивхи, эвены.

\section{STUDY OF THE FACTORS OF THE FORMATION OF ELEMENTAL IMBALANCE IN THE BODY OF ADOLESCENTS OF DIFFERENT ETHNIC GROUPS IN KHABAROVSK TERRITORY}

\author{
A.O. Nesterenko*1, G.P. Evseeva ${ }^{2}$, E.D. Tselykh \\ ${ }^{1}$ Far Eastern State Transport University, Khabarovsk, Russia \\ ${ }^{2}$ Khabarovsk Branch of the Far Eastern Scientific Centerof Physiology and Pathology of Respiration - \\ Research Institute of Maternity and Childhood Protection \\ * e-mail: alenushka_3@inbox.ru
}

ABSTRACT. Adolescents of the Nivkhs, Evens and Russian nationalities were examined. Elemental imbalance was revealed in the blood serum and the hair. We found that the elemental composition of biosubstrates depends on nutrition, territory, high content of Th and Uin the body.

KEYWORDS: adolescents, trace elements, hair, blood serum, Nivkhs, Evens.

\section{ВВЕДЕНИЕ}

В периоды полового созревания подростки становятся чувствительными к дисбалансу микроэлементов в организме. Роль микроэлементов активно изучается, однако исследований по биологической роли урана и тория в организме представлено недостаточно.

Цель работы - выявить особенности формирования элементного дисбаланса в сыворотке крови и волосах подростков разных этнических групп Хабаровского края.

\section{МАТЕРИАЛЫ И МЕТОДЫ}

Обследованные подростки были разделены на четыре группы $(n=121)$, возраст $-14,8 \pm 0,5$ лет: нивхи, эвены и русские в Николаевском и Охотском районах. Содержание $\mathrm{Cu}, \mathrm{Mo}, \mathrm{Co}$, Th и $\mathrm{U}$ в сыворотке крови и волосах определено методом атомно-эмиссионной спектроскопии (ICP-MS Elan 9000, Канада). Элементный состав питания изучен с помощью анкетирования. Статистический анализ проведен с использованием стандартных методов вариационной статистики.

\section{РЕЗУЛЬТАТЫ И ОБСУЖДЕНИЕ}

Анализ элементного состава сыворотки крови нивхов и эвенов выявилвысокую концентрацию $\mathrm{Cu}$, превышающую норматив в $2,69-1,22$ раза соответственно ( $p \leq 0,001)$, Мо (в 5,49-3,82 раза, $p \leq 0,001)$, в то время как в группах русских определен дефицит Сu (ниже норматива в $1,47-1,62$ раза, $p \leq 0,001$ ), Мо (в $1,17-1,35$ раза, $p \leq 0,001)$. Концентрация Со дефицитна во всех группах, однако в сыворотке крови нивхов и эвенов в $1,20-6,72$ раза ниже норматива $(p \leq 0,001)$, в то время как в группах русских составила менее $10 \%$. В волосах всех групп выявлен дефицит $\mathrm{Cu}$, Mo, Co $(p \leq 0,05-0,001)$. Однако в волосах коренных народов концентрация меди выше по сравнению с русскими в 1,17-1,46 раза, а концентрация Мо выше в 
1,5 раза по сравнению с русскими $(p \leq 0,05)$. Содержание Со в группах нивхов и эвенов достоверно выше по сравнению с русскими в $1,31-1,67(p \leq 0,001)$. Выявлены «средние» по силе корреляционные взаимосвязи дефицита Мо $(r=0,337-0,348)$ и $\mathrm{Co}(r=0,478-0,367)$ в рационах питания с уровнем элементов в волосах в группах эвенов и нивхов соответственно и Мо у русских подростков Николаевского района $(r=0,345)$. В биосубстратах подростков установлены высокие концентрации Th и U: в сыворотке крови эвенов, превышает нормативы в $2,79-15,16$ раза, нивхов в $3,18-3,20$ раза соответственно $(p \leq 0,001)$. В группах русских подростков концентрация Тh и U в сыворотке крови соответствуют верхней границе норматива. Содержание Th в волосах нивхов и эвенов выше по сравнению с русскими в 1,27-2 раза, а $\mathrm{U}$ - в $1,35-1,5$ раза $(p \leq 0,001)$. Этнические различия достоверны $(p \leq 0,001)$.

Корреляционный анализ выявил значимые зависимости: в сыворотке крови нивхов и эвенов корреляции Мо и Со с Тh составили $r=0,376-0,480$, у русских $-r=-0,568 \ldots-0,998$. В сыворотке крови подростков Охотского района установлена связь $\mathrm{U} \mathrm{c} \mathrm{Cu}$, Мо, Со: эвены - $r=0,421-0,512$, русские $r=-0,993 \ldots-0,999$. В волосах выявлены корреляции радиоактивных веществ с Мо и Сo: Th/Мо эвены $r=-0,450$, русские $-r=-0,751$; U/Мо эвены $-r=-0,667$; Тh/Со нивхи $-r=-0,717$, русские $-r=-0,874$; $\mathrm{U} / \mathrm{Co} \mathrm{нивхи} \mathrm{и} \mathrm{эвены}-r=-0,436 \ldots-0,994$.

Наблюдается снижение концентраций $\mathrm{Co}, \mathrm{Cu}, \mathrm{Mo}, \mathrm{Th}, \mathrm{U}$ в волосах русских «с севера на юг». В группе нивхов аккумуляция $\mathrm{Co}$, Th, U в волосах выше, чем в группе эвенов, проживающих севернее $(p \leq 0,001)$. Изменения элементного состава биосубстратов, вероятно, обусловлены особенностями биогеохимической провинции и климатическими условиями (дискомфортные условия в Охотском районе и гипокомфортные - в Николаевском), что согласуется с динамикой установленных концентраций микроэлементов.

\section{ВЫВОДЫ}

Во всех обследованных группах установлен элементный дисбаланс. Выявлены этнические различия в накоплении $\mathrm{Co}, \mathrm{Mo}, \mathrm{Th}, \mathrm{U}$ в волосах $(p \leq 0,001)$ и выраженная аккумуляция в группах коренного населения. На формирование элементного дисбаланса влияют особенности питания, бигеогеохимические особенности региона проживания. 